\title{
Microbial Analysis of Drinking Water from Nadi to Lautoka Area in Viti Levu Fiji
}

Danian Singh and Kelera Railoa

\begin{abstract}
Introduction: Access to sufficient and safe drinking water is essential for human health and welfare. Countries in the Pacific Region like Fiji frequently face issues with access to safe drinking water and supply problems. Fluctuations in water resource availability, often untreated water and faulty treatment facilities, pollution, lack of proper water management frameworks and most importantly lack of water monitoring resources are all factors that influence Pacific Island Countries. Apart from this, Pacific Islands and their water supplies are susceptible to climate hazards such as floods, cyclones and drought. The Western Division of Fiji Islands is highly prone to adverse climatic conditions; therefore regular monitoring of the various drinking water sources is essential to ensure safety of people. This study was conducted in the Lautoka to Nadi corridor where 25 sites were randomly selected for water analysis processing from January to February 2019.
\end{abstract}

Method: Physio-chemical analysis, such as measuring $\mathrm{pH}$ and turbidity as well as simple microbial analysis, was conducted on the water samples. Specific growth media was used to determine the different types of bacteria (Coliform, Escherichia coli and Salmonella enterica) present in the water samples; Lauryl Tryptose Broth, Eosin Methlylene Blue Agar, Xylose Lysine Deoxycholate was used. Turbidity was measured using a digital turbidity meter and $\mathrm{pH}$ value was determined employing a digital meter.

Results and Discussion: From the analysis it was determined that overall the $\mathrm{pH}$ levels of samples (6.02-8.30) falls within the permissible limits; whereas turbidity was generally higher in untreated water sources with ranges from 3 to 8 nephelometric turbidity units. Microbial content was higher in untreated water samples. Other sources such as springs and creeks recorded the most significant number of Coliforms when compared to other sources and some samples indicated the presence of Escherichia coli and Salmonella enterica. 
Conclusion: From the study it can be concluded that all the water samples tested positive for bacterial contamination particularly Coliforms and it was higher in untreated water. Water from the Municipality had almost all physiochemical and bacteria parameters within the World Health Organization limits, except for turbidity which was generally above 1NTU. However, this was not the case for untreated water which in some samples contained high levels of harmful bacteria. Monitoring needs to be carried out to better understand water quality and implement counter measures.

Keywords: Drinking water, bacteria, water contamination, Fiji.

Danian Singh is affiliated with School of Science and Technology, University of Fiji, Fiji Islands. Contact-danian_singh@yahoo.com.au (Corresponding author).

Kelera Railoa is quality officer at Douglas Pharmaceuticals, Nadi, Fiji Islands. Contact-1elah.alyssa@gmail.com 


\section{Introduction}

Water is the key to survival of humans and many living organisms. Its unavailability or scarcity is arguably amongst one of the world's most serious issues with around $80 \%$ of all diseases related to water scarcity and water related problems such as inadequate sanitation and consumption of contaminated water (Solomon et al., 2011). In recognition of the importance of clean and safe drinking water for the good health of people, the United Nations has declared access to clean water an essential human right. However, in many countries across the globe including the Pacific Islands where drinking water is obtained either from surface or groundwater sources, attaining this basic human right has become relatively difficult (Mosley, Singh, \& Aalbersberg, 2005). A number of residents in Viti Levu, Fiji, obtain their drinking water from unfiltered and untreated wells, springs, rainwater locations, rivers and creeks (Lee, 2007). In these communities there is an increased susceptibility to water borne diseases. Approximately $45 \%$ of Fiji's inhabitants dwell in the rural and coastal areas and about $70 \%$ of these people consume untreated water (Government of Fiji, 2013). Some of these water sources have become contaminated and pose a risk to health and the economic status of a small developing nation (Amin, Ali, Anwar, Khattak, 2012).

Poor management of human and livestock waste and the release of industrial waste into water-ways has introduced contaminants such as heavy metals, harmful bacteria, viruses and nitrates (G. Lee \& Brodie, 1982; McAllister \& Topp, 2012; Wardrop, Hill, Dzodzomenyo, Aryeetey, \& Wright, 2018). Thus, altering the chemistry of our water systems. For example, an increase in levels of nutrients such as Nitrogen and Phosphorous not only leads to increased turbidity but also leads to the amplified growth of organisms such as algae and other microbes otherwise termed as eutrophication (Amin et al, 2012).

History has indicated the significant role that water plays in the dispersion of various protozoans, bacterial and viral diseases (Cunningham \& Cunningham, 2005). Water that has been contaminated with fecal matter can spread a broad variety of dangerous diseases such as dysentery, hepatitis, typhoid and diarrhoea (Amin et al, 2012). Fiji's Ministry of Health records diarrhoea as the second most frequently reported disease between 2017 to 2018 (Ministry of Health, Fiji, 2018) with Escherichia coli documented as one of the major causes usually contracted through untreated drinking water (Behiry, Abada, Ahmed, \& Labeeb, 2011; Amin et al, 2012). Coliform has also 
been extensively documented in water quality studies with research revealing that although Coliform is usually harmless, its presence can indicate the occurrence of other pathogenic microbes (Saxena, Bharagava, Kaithwas, \& Raj, 2015; Solomon et al., 2011). Typhoid has been commonly linked with poor sanitation and hygiene and is associated with the presence of the pathogenic bacteria Salmonella enterica which is transmitted through the consumption of contaminated food or water. Typhoid fever is becoming a significant health problem in Fiji with the number of reported cases escalating in the last decade. Figures grew from less than five in every 100,000 cases in 2005 to about 44 in every 100,000 in 2011 (Thompson et al., 2014).

Oceania continues to be troubled by water woes and water borne illnesses due to increasing pollution, poor infrastructure, lack of appropriate polices and finance and accessibility to proper water resources (Naica \& Ferreira, 2016). These factors are exacerbated by the effects of climate change further increasing the susceptibility of vulnerable rural and coastal communities (Government of Fiji, 2013). A developing nation such as Fiji is constantly undergoing changes to its landscape. Subsequently, the overall quality of water will alter in response to the dynamic environment. As such, tracking these changes and monitoring water quality becomes paramount so that we make progress towards cleaning polluted water bodies and that appropriate awareness and preventative methods can be employed.

Fiji lacks important water quality data especially in Western Viti Levu (Mosley et al., 2005) and there is a need to mitigate the prevalence of water- borne illness. This study was conducted as an attempt to collect data and to investigate the physical, chemical and biological qualities and parameters of drinking water in the Viti Levu's Western Division playing particular attention to the Nadi-Lautoka corridor. 


\section{Method}

A total of 25 sites within the Nadi to Lautoka corridor were randomly selected for analysis. These sites comprised of both urban and rural residential areas. The drinking water sources comprised of springs, wells, boreholes, creeks, rainwater stored in tanks. The $\mathrm{pH}$ and turbidity were determined by American Society for Testing and Materials International method (Amin et al., 2012). Microbial analysis was carried out for Coilforms, Escherichia coli and Salmonella enterica. Samples were collected from January to February in 2019. Water samples for bacteriological testing was collected in $500 \mathrm{~mL}$ sterilized Schott Duran bottles and placed in an ice box. For $\mathrm{pH}$ and turbidity analysis $500 \mathrm{~mL}$ sterilized plastic bottles were used to store the water.

Sample bottles were transported to the laboratory for analysis and testing was completed within one hour of collection. This was done prevent the over growth of microorganisms which could have an effect on the total bacterial count.

$p H$

The balance between acid and base in drinking water was assessed by its $\mathrm{pH}$ value (Akter et al., 2016). The $\mathrm{pH}$ of the water samples was measured using a digital $\mathrm{pH}$ meter (Hanna Instruments, USA).

\section{Turbidity}

Turbidity is simply the measure of the clarity and transparency of water (Amin et al., 2012). Drinking water turbidity was measured using a digital turbidity meter (TB1000, USA) and the results were expressed in nephelometric turbidity units (NTU) (Mosley et al., 2005).

\section{Bacteriological Analysis}

Multi-tube fermentation and Most Probable Number techniques were employed as described by Amin et al. (2012). Selective Culture Medium was used to confirm the growth of a specific type of microbe.

\section{Coliform}

Coliform bacteria was isolated and identified using Most Probable Number (MPN) where diluted samples of Lauryl Tryptose Broth 1:10 and Brilliant Broth was used as medium for growth (Amin et al., 2012; Mosley et al., 2005). Samples were incubated for 24 hours at a temperature of $44.5^{\circ} \mathrm{C}$. 


\section{Escherichia coli}

This microbe was isolated and identified by employing streaking method (Kenneth, 2011). Streak loop inoculums from EC Broth tube which were positive on Eosin Methlylene Blue Agar plates were then incubated for 48 hours at a temperature of $35^{\circ} \mathrm{C}$. The colonies of E.coli were identified biochemically by using API 20E kit (API system France).

\section{Salmonella}

This microbe was detected using streak plate method on selective media (Kenneth, 2011). Xylose Lysine Deoxycholate (XLD) agar was used and this was then incubated for 20 hours at $37^{\circ} \mathrm{C}$. The colonies of Salmonella enterica were identified biochemically by using API 20E kit (API system France).

\section{Results and Discussion}

$p H$

The $\mathrm{pH}$ of the samples collected ranged from 6.02 to 8.30 with an average $\mathrm{pH}$ of 6.91 over 25 sites. The lowest and highest $\mathrm{pH}$ readings were recorded from untreated water sources i.e. $\mathrm{pH} 6.02$ was recorded for well water which was unprotected and $\mathrm{pH} 8.30$ from a creek system. Overall (in reference to Figure $1)$, the $\mathrm{pH}$ ranges across all 25 sites fall within the permissible limits (6.5 to 8.5) as outlined by Akter et al., 2016. Variation in $\mathrm{pH}$ values may be due to an increase in temperature that can also inhibit the solubility of carbon dioxide (Amin et al., 2012; Mosley et al., 2005). Changes also come about due to leakages in the supply chain or seepage of waste products into these water sources (Amin et al., 2012).

Decline in $\mathrm{pH}$ makes water acidic in nature and can leach metals in pumps and pipes (Mosley et al., 2005). Water with a $\mathrm{pH}$ less than 7 will tend to have a soft mouth feel and a bitter taste however alkaline water has a $\mathrm{pH}$ greater than 7 and has a soda taste, feels slippery and will be hard in nature (Amin et al., 2012).

\section{Turbidity}

Turbidity is typically a reliable and affordable indicator of water quality. As a visual guide, crystal clear water would have turbidity of less than 1 NTU while readings greater than 4 NTU would have a visible cloudiness. The World Health Organization establishes that the turbidity of drinking water should 
not be greater than 5 NTU and should ideally be less than 1 NTU. Results from this study reveal that while local municipal water supplies may not fulfill the ideal criteria of less than 1 NTU the average of 4 NTU was recorded from 8 municipal water supplies is within WHO's acceptable limits.

The remaining water sources, however, yielded an average of 7 NTU. Samples collected from Rainwater sources were 8 NTU while Borehole water had an average of $6 \mathrm{NTU}$. The only creek water source sampled had turbidity of 8 NTU. These relatively high turbidity levels are generally expected in untreated water sources. Due to the presence of sediments and particulate matter that would otherwise be filtered off during water treatment (World Health Organization, 2017). Water sources will tend to be murkier as well following natural disturbances such as intense rainfall or works being undertaken upstream (World Health Organization, 2017). 
Table 1: Physio-chemical and Bacteriological analysis results.

\begin{tabular}{|c|c|c|c|c|c|c|c|}
\hline Site & Source & $\begin{array}{c}\text { Treated } \\
\text { or } \\
\text { Untreated }\end{array}$ & $\begin{array}{l}\text { Coliforms } \\
\text { (MPN per } \\
\text { 100ml) }\end{array}$ & $\begin{array}{l}\text { Escherichia } \\
\text { coli }\end{array}$ & Salmonella & pH & $\begin{array}{c}\text { Turbidly } \\
\text { (NTU) }\end{array}$ \\
\hline 1 & Municipal & Treated & $<3$ & - & - & 7.07 & 3 \\
\hline 2 & Spring & Untreated & 250 & + & - & 6.71 & 7 \\
\hline 3 & Municipal & Treated & $<3$ & - & - & 7.03 & 4 \\
\hline 4 & Well & Untreated & $\geq 2500$ & + & + & 6.98 & 8 \\
\hline 5 & Well & Untreated & $\geq 2300$ & + & - & 6.64 & 7 \\
\hline 6 & $\begin{array}{l}\text { Rain } \\
\text { water }\end{array}$ & Untreated & 1100 & + & - & 6.05 & 8 \\
\hline 7 & Municipal & Treated & $<3$ & - & - & 7.2 & 3 \\
\hline 8 & Municipal & Treated & $<3$ & - & - & 7.02 & 3 \\
\hline 9 & Municipal & Treated & $<3$ & - & - & 7.08 & 4 \\
\hline 10 & Well & Untreated & $\geq 250$ & + & - & 6.02 & 7 \\
\hline 11 & Spring & Untreated & $\geq 2400$ & + & - & 6.57 & 8 \\
\hline 12 & Spring & Untreated & $\geq 2400$ & - & - & 6.4 & 7 \\
\hline 13 & $\begin{array}{c}\text { Rain } \\
\text { water }\end{array}$ & Untreated & 240 & - & - & 6.2 & 7 \\
\hline 14 & Well & Untreated & 2400 & + & - & 6.03 & 8 \\
\hline 15 & Borehole & Untreated & 11200 & - & + & 7.3 & 8 \\
\hline 16 & Borehole & Untreated & $\geq 2000$ & - & + & 7.22 & 5 \\
\hline 17 & Creek & Untreated & 1100 & - & + & 8.3 & 8 \\
\hline 18 & Spring & Untreated & 1100 & - & + & 6.63 & 7 \\
\hline 19 & Borehole & Untreated & $<3$ & - & - & 7.6 & 6 \\
\hline
\end{tabular}




\begin{tabular}{|c|c|c|c|c|c|c|c|}
\hline 20 & Borehole & Untreated & 23 & - & - & 7.55 & 6 \\
\hline 21 & Borehole & Untreated & 23 & - & + & 7.3 & 7 \\
\hline 22 & Municipal & Treated & $<3$ & - & - & 7.05 & 4 \\
\hline 23 & Municipal & Treated & $<3$ & - & - & 7.04 & 3 \\
\hline 24 & Municipal & Treated & $<3$ & - & - & 7.06 & 4 \\
\hline 25 & Well & Untreated & $\geq 450$ & + & - & 6.6 & 7 \\
\hline
\end{tabular}

+ indicates positive for bacteria

- indicates negative for bacteria

\section{Microbial Content}

The biological testing of the water samples comprised of microbial analysis for the presence of Coliforms, Escherichia coli and Salmonella enterica bacteria. All 8 municipal water samples yielded replica results of $<3$ MPN per $100 \mathrm{~mL}$ for Coliforms and zero detection of E.coli and Salmonella enterica. Untreated water sources however revealed alarming bacterial counts. For instance, one borehole water source recorded the most significant content of Coliforms with a total of 11,200 MPN per $100 \mathrm{~mL}$ and tested positive for the presence of Salmonella enterica. While Coliforms do not directly affect human health, it's often an indicator of fecal contamination due to E. coli or the presence of other harmful pathogens such as Salmonella enterica. A closer look at the data obtained from all 25 sites shows that higher MPN counts for Coliforms does not always necessarily indicate possible fecal contamination i.e. one Borehole source recorded Coliforms of $23 \mathrm{MPN}$ per $100 \mathrm{~mL}$, was negative for E.coli and positive for Salmonella enterica while a second Borehole source recorded the same for Coliforms but was negative for both E.coli and Salmonella enterica. The five well water sources tested had alarming Coliform counts ranging from 450 - 2500 MPN per $100 \mathrm{~mL}$. Four out of the five well water samples tested positive for E.coli and one tested positive for both E.coli and Salmonella enterica. The four spring water samples also had high Coliform counts ranging from 250 - 2400 MPN per $100 \mathrm{~mL}$ with 2 samples testing positive for E.coli and 2 tested positive for Salmonella. It is likely that these water sources are in close proximity to livestock and have faced fecal contamination. Also, these 
drinking water sources could have been situated near human waste disposal sites which could have led to contamination (Vantarakis et al., 2016). The same is likely for rainwater and creek water samples. Samples collected from five borehole sites gave variable results with one site having almost similar microbial levels as the municipal water supply. Two sites had Coliform counts of 23MPN per $100 \mathrm{~mL}$. Both samples were negative for E.coli and one was positive for Salmonella enterica. Two borehole sites recorded $>2000$ and 11,200 MPN per 100mL Coliforms with both showing negative results for E.coli and positive for Salmonella enterica.

The observed microbial testing results confirm that Fiji's Municipal water supplies meet drinking water standards and should be the preferred source of drinking water nationwide. The reality though is that there still exists rural communities which do not have the luxury of piped water and rely on alternative sources such as borehole, spring, rainwater collected in tanks and well water. In this case, water quality monitoring and routine disinfection should be carried out in these areas to ensure that communities who depend on these water sources have access to clean and safe drinking water.

\section{Conclusion}

From this study it can be stated that most of the physio-chemical and bacteriological parameters are within the permissible limits for treated water except for turbidity which was above 1 NTU for the drinking samples. Presence of Coliforms was discovered to exist in all the samples including for the Municipality. The primary cause of this can be leakage in pipes which may cause pollutants and waste to enter into the system. Untreated water sources contained the highest amount of bacterial contamination with indication of E.Coli and Salmonella enterica. This can be due to poorly constructed wells which may also be near farms and septic tanks near sources. The results indicate that drinking water is highly susceptible to contamination therefore it is essential that regular monitoring be done on the larger scale which includes all the areas within Fiji Islands. 


\section{References}

Akter, T., Jhohura, F. T., Akter, F., Chowdhury, T. R., Mistry, S. K., Dey, D., ... Rahman, M. (2016). Water Quality Index for measuring drinking water quality in rural Bangladesh: a cross-sectional study. Journal of Health, Population and Nutrition, 35(1), 4. https://doi.org/10.1186/s41043-016-0041-5

Amin, R; Ali, S.S; Anwar, Z; Khattak, J. (2012). Microbial Analysis of Drinking Water and Water Distribution System in New Urban Peshawar. Current Research Journal of Biological Science, 6(4), 731-737.

Behiry, I. K., Abada, E. A., Ahmed, E. A., \& Labeeb, R. S. (2011). Enteropathogenic Escherichia coli associated with diarrhea in children in Cairo, Egypt. TheScientificWorldJournal, 11, 2613-2619. https://doi.org/10.1100/2011/485381

Cunningham, W., \& Cunningham, M. (2005). Environmental science a global concern (8th ed.). New York: McGraw-Hill Education.

Government of Fiji. (2013). Kalokolevu villagers welcome access to clean drinking water. Retrieved from The Fijian Government website: http://www.fiji.gov.fj/Media-Center/Press-Releases / KalokolevuVillagers-Welcome-Access-To-Clean-Drink.aspx

Kenneth, S. (2011). Seasonal prevalence of faecal indicators and enteric pathogens in Suva lagoon (University of the South Pacific.). Retrieved from

http:/ / digilib.library.usp.ac.fj/gsdl/collect/usplibr1/index/assoc/HAS Ha563.dir/doc.pdf

Lee, C. (2007). Students' assignment: Help Fijians get clean drinking water. Retrieved from Institute of the Environment and Sustainability at UCLA website: https://www.ioes.ucla.edu/news/students-assignment-helpfijians-get-clean-drinking-water/.

Lee, G., \& Brodie, J. (1982). Drinking water quality in a number of South Pacific Island countries. Suva.

McAllister, T. A., \& Topp, E. (2012). Role of livestock in microbiological contamination of water: Commonly the blame, but not always the source. Animal Frontiers, 2(2), 17-27. https://doi.org/10.2527/af.20120039

Ministry of Health, Fiji. (2018). National Notifiable Disease Surveillance Bulletin. Vol. 1. Suva.

Mosley, L., Singh, S., \& Aalbersberg, B. (2005). Water Quality Monitoring in Pacific Island Countries. Water Quality Monitoring in Pacific Island 
Countries. Suva.

Naica, I., \& Ferreira, C. (2016). Freshwater accessibility and challenges in rural areas of Fiji: a case study of Kalabu Village. GOT - Geography and Spatial Planning Journal, 9(1), 213-236. https://doi.org/10.17127/got/2016.9.010

Saxena, G., Bharagava, R. N., Kaithwas, G., \& Raj, A. (2015). Microbial indicators, pathogens and methods for their monitoring in water environment. Journal of Water and Health, 13(2), 319-339. https://doi.org/10.2166/wh.2014.275

Solomon, A., Ahmed, Z., Biruktawit, K., Amare, D., Solomon, A., \& Endalew, Z. (2011). "Bacteriological analysis of drinking water sources ." African Journal of Microbiology Research, 18(5), 2638-2641. https://doi.org/10.5897/AJMR11.218

Thompson, C. N., Kama, M., Acharya, S., Bera, U., Clemens, J., Crump, J. A., ... Mulholland, K. (2014). Typhoid fever in Fiji: a reversible plague? Tropical Medicine \& International Health: TM \& IH, 19 (10), 1284-1292. https://doi.org/10.1111/tmi.12367

Vantarakis, A., Paparrodopoulos, S., Kokkinos, P., Vantarakis, G., Fragou, K., \& Detorakis, I. (2016). Impact on the Quality of Life When Living Close to a Municipal Wastewater Treatment Plant. Journal of Environmental and Public Health, 2016, 1-8. https://doi.org/10.1155/2016/8467023

Wardrop, N. A., Hill, A. G., Dzodzomenyo, M., Aryeetey, G., \& Wright, J. A. (2018). Livestock ownership and microbial contamination of drinkingwater: Evidence from nationally representative household surveys in Ghana, Nepal and Bangladesh. International Journal of Hygiene and Environmental Health, 221(1), 33-40. https://doi.org/10.1016/j.ijheh.2017.09.014

World Health Organization. (2017). Water Quality And Health - Review Of Turbidity: Information for regulators and water suppliers. In Who/ Fwc/Wsh/17.01. Retrieved from https://www.who.int/water_sanitation_health/publications/turbidityinformation-200217.pdf 